\title{
Effect of the Bromine-Based Flame Retardant Plastic Pyrolysis of Hydrotalcite
}

\author{
N. Morita ${ }^{1}$, Y. Kawabata ${ }^{1}$, T. Wajima ${ }^{2}$, A. T. Saito ${ }^{2}$, and H. Nakagome ${ }^{2}$ \\ ${ }^{1}$ Department of Urban Environment System at Chiba University, Japan. \\ ${ }^{2}$ Chiba University, Japan.
}

\begin{abstract}
In this study, a method is presented to decrease halogen compounds in the product oil from thermolysis of polystyrene and polypropylene mixed plastic spiked with tetrabromobisphenol A. A mixture of hydrotalcite and plastic was pyrolyzed in a glass reactor at $400{ }^{\circ} \mathrm{C}$ under a nitrogen atmosphere. Bromine compounds in the residual substances were measured. The yield of product oil increased using hydrotalcite as an additive. The bromine compounds that were the major ingredients in the oil after thermolysis at $400{ }^{\circ} \mathrm{C}$ from the mixed plastic, which also included toluene, ethyl benzene, styrene, and 1-methylethyl benzene, were 2-bromohexane, 3-bromo-1-propenyl benzene, 4,5-dibromodecane, 1-bromomethylbenzene, 3-bromophenol, and 4-bromo-2,6-dimethylbenzaniline. However, bromine compounds were not detected in the product oil, residue, or gas when hydrotalcite was added. After the thermolysis of the plastic, bromine compounds in the product oil may decrease because bromine was captured by the added hydrotalcite.
\end{abstract}

\section{Introduction}

Plastics originate from fossil fuels and are becoming a problem because of the large quantity of waste. Methods for recycling plastic include thermal, chemical, and material recycling. Chemical recycling by pyrolysis is capable of returning plastics to their raw materials, and has attracted attention for making plastic derived fuel. There is an ever increasing volume of electronic products and associated waste electrical and electronic equipment (WEEE). Moreover, new models of electronic devices are replacing the old at a higher rate than ever before. WEEE includes computers, cellphones, hair dryers, and refrigerators, as well as the cathode-ray tube television [1]. However, the flame retardant materials added in these plastics form a product oil that includes halogen compounds. There are many recyclable materials, e.g., glass and metal; however, the energy consumption of the recycling process is problematic. Protecting the environment is desirable, but there are now more than 15 types of plastic commonly used in electronics [2]. The quantity of WEEE per person in a member nation of the 27 European Union (EU27) countries was estimated as 17 $\mathrm{kg}$ per person in 2005 [3]. The EU has introduced laws for the reuse and recycling of plastics to reduce landfill, and control WEEE destruction by thermal decomposition [4]. Plastics can be converted into gas for use as chemical raw materials, and fuel. Oil and residual carbon produced by pyrolysis can also be useful [5]. There has been considerable research on pyrolysis using catalysts and the chemical recycling of plastic [6-17]. For example, the

\footnotetext{
a Corresponding author: Naoyuki_Morita@chiba-u.jp
}

yield of the product oil can be increased using ZSM-5 zeolite red mud mesoporous molecular sieve in the pyrolysis of plastics [18, 19]. However, the toxic brominated flame retardant is a problem for plastic recycling of household electrical appliances [20-24]. The generation of harmful byproducts has been studied to prevent the release of halogen gas, and additives have been used to promote recycling [22]. For example, polybrominated compounds mixed with polypropylene (PP), polyethylene, polystyrene (PS), and polyvinyl chloride have been decomposed safely with a carbon complex of calcium carbonate [25]. Additionally, the quality of the pyrolysis oil has been improved using the commercial hydrogenation catalyst DHC-8 [26]. The yield of product oil was improved to $96 \%$ from $93 \%$ when the zeolite catalysts, H-USY or H-Beta, were used in a steam contact process for pyrolysis [27]. The content of the bromine compounds in the product oil was decreased by adding hydrotalcite (HT) in the pyrolysis of brominated plastic [28-30]. HT is composed of layers of hydroxides that can form a metal complex hydroxide, containing anionic hosts and $\mathrm{Mg}^{2+}$ and $\mathrm{Al}^{3+}$ interlamellar guests [31, 32]. HT is an ion exchanger [31-34] and a catalyst [35] for gas removal [36, 37], and these applications have been receiving increasing attention in recent years [38].

The high anion exchange ability of HT, which is similar to organic ion exchange resins, has attracted attention as an adsorbent for the removal of various pollutants from water. The anionic adsorption properties include substitution reactions with chemicals such as 
borate, nitrate, fluoride, phosphate, sulfate, chromate, arsenic acid, and selenic acid. The anionic adsorption mechanism of HT has been proposed as an interlamellar complex formed of anionic exchange reactions [39]. In addition, HT has attracted attention as a catalyst, and reports have shown a yield increase to $77 \%$ from $62 \%$ in biodiesel fuel generation [40, 41].

In this study, pyrolysis at $400^{\circ} \mathrm{C}$ of PS and PP plastic mixtures spiked with tetrabromobisphenol A (TBBA) is examined using HT. The effects of additives on the product oil and the behavior of bromine compounds is evaluated.

\section{Materials and Methods}

\subsection{Materials}

Plastic samples containing bromine were prepared by mixing $10 \mathrm{~g}$ of PSJ PS) (Asahi Kasei Chemicals Corporation Co., Ltd.) and $10 \mathrm{~g}$ of PP (Teijin Co., Ltd.) with $2 \mathrm{~g}$ of TBBA (Tokyo Chemical Industry Co., Ltd., Tokyo, Japan). To reduce bromine compounds in the product oil, synthetic HT, KW-1000, (Kyowa Chemical Industry Co., Ltd.), sea sand (Wako Pure Chemical Industries, Ltd.), molecular sieve 4A (Wako Pure Chemical Industries, Ltd.), and molecular sieve 13X (Wako Pure Chemical Industries, Ltd.) were used as additives. The experimental conditions are listed in Table 1.

Table 1: Experimental conditions used in this study

\begin{tabular}{|c|l|}
\hline Condition & \multicolumn{1}{c|}{ Contents of the sample } \\
\hline I & $\begin{array}{l}\text { Polystyrene (PS) +Polypropylene(PP)+ } \\
\text { Tetrabromobisphenol A (TBBA) }\end{array}$ \\
\hline II & PS + PP + TBBA + Sea sand \\
\hline III & PS + PP + TBBA + Molecular sieves 4A \\
\hline IV & PS + PP + TBBA + Molecular sieves 13X \\
\hline V & PS + PP + TBBA + Hydrotalcite \\
\hline
\end{tabular}

\subsection{Experimental apparatus and procedures}

The experimental apparatus used in this study is shown in Figure 1. A 22-g quantity of PS+PP+TBBA, or mixtures with an additive $(20 \mathrm{~g})$ was added to a glass reactor. The reactor was purged with nitrogen gas at a flow rate of 50 $\mathrm{mL} / \mathrm{min}$ for $60 \mathrm{~min}$ to remove oxygen. After oxygen substitution, the flow of nitrogen gas was stopped and the pyrolysis experiment was performed. The temperature of the plastic was measured as the initial temperature, and the reactor temperature was increased to the decomposition temperature $\left(400{ }^{\circ} \mathrm{C}\right)$ at a heating rate of 5 ${ }^{\circ} \mathrm{C} / \mathrm{min}$. The gases produced by pyrolysis were condensed and recovered. Non-condensable gases, which pass through the condenser, were collected in a gas pack via bubbling in an alkaline aqueous solution. Residue remained in the reactor after pyrolysis. The mass balance of the pyrolysis products (oil, gas, and residue) was calculated after the experiment. The pyrolysis products obtained after experiments under each condition were analyzed.

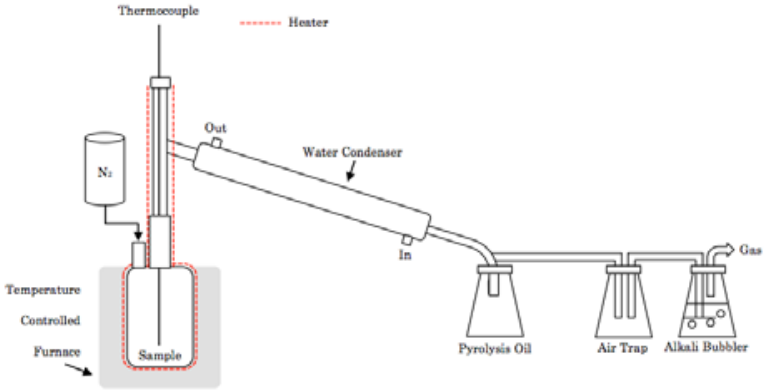

Figure 1. Experimental apparatus

\subsection{Analysis}

The oils were analyzed by gas chromatography/mass spectrometry (Shimadzu GC-MS-QP2010 Ultra) using a RTX-624 column (thickness: $1.8 \mu \mathrm{m}$, inner diameter: 60 $\mathrm{mm}$, length: $0.32 \mathrm{~mm}$ ) with pure helium as the carrier gas. The main compounds in the oil were identified using a gas chromatography/mass spectrometry spectral library. The analyses were performed at a temperature of $40{ }^{\circ} \mathrm{C}$ for $30 \mathrm{~min}$, and then the temperature was increased to $230{ }^{\circ} \mathrm{C}$ at a rate of $5{ }^{\circ} \mathrm{C} / \mathrm{min}$. The structural change in the sample before and after the experiment was determined by X-ray diffraction analysis (Bruker, D2PHASER), and the morphologies and element distribution maps of the samples before and after the experiment were observed with a scanning electron microscope (Hitachi High-Tech, TM3030) equipped with energy-dispersive spectroscopy. The alkaline aqueous solution of bubble-trapped bromine compounds formed from non-condensable gases was analyzed by ion chromatography (Shimadzu, HIP-SP). The product gas that passed through the alkaline aqueous solution was recovered by a gas pack and analyzed using a Shim-pack column $(150-\mathrm{mm}$ long $\times$ 4.6-mm inner diameter) and a CDD-10Asp detector as part of a highperformance liquid chromatography system.

\section{Results and Discussion}

\subsection{Product oil yield}

The yields of product oil from the pyrolysis experiments are shown in Figure 2, which varied for different additives. The case using HT showed the highest yield, which was approximately 1.5 times that of the additivefree case. This result indicates the catalytic action of HT $[40,41]$. In addition, the gases generated by pyrolysis were all less than $1 \mathrm{~L}$.

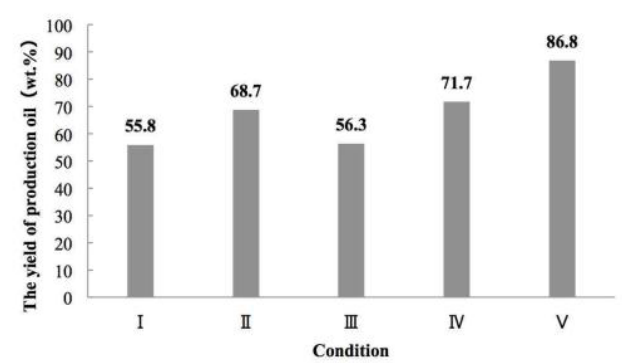

Figure 2. Yield of production oil 


\subsection{Product oil components}

Components of the product oils are given in Table 2. All the oil products contained toluene, ethylbenzene, styrene, and 1-methylethyl benzene. Bromine compounds obtained from the product oil included 2-bromohexane, 3-bromo-1-propenyl benzene, 4,5-dibromodecane, 1- bromomethylbenzene, 3-bromophenol, and 4-bromo-2,6dimethylbenzaniline.

The results in Table 2 show that bromine compounds were not detected in the oil produced under condition $\mathrm{V}$, which is the plastic containing HT.

Table 2. Components of product oils obtained under each experimental condition.

\begin{tabular}{|c|c|c|c|c|c|c|}
\hline \multirow[b]{2}{*}{ Compound } & \multirow[b]{2}{*}{ Formula } & \multicolumn{5}{|c|}{ Condition } \\
\hline & & I & II & III & IV & V \\
\hline Toluene & $\mathrm{C}_{6} \mathrm{H}_{5} \mathrm{CH}_{3}$ & o & o & $\circ$ & o & 0 \\
\hline 4-Methylheptane & $\mathrm{C}_{6} \mathrm{H}_{14}$ & $\circ$ & 0 & $\circ$ & nd & $\circ$ \\
\hline 2-Bromohexane & $\mathrm{C}_{6} \mathrm{H}_{13} \mathrm{Br}$ & $\circ$ & $\circ$ & nd & nd & nd \\
\hline 2,3-Dimethyl-2-heptane & $\mathrm{C}_{9} \mathrm{H}_{18}$ & $\circ$ & nd & nd & $\circ$ & nd \\
\hline 2,4-Dimethyl-1-heptene & $\mathrm{C}_{9} \mathrm{H}_{18}$ & nd & nd & $\circ$ & nd & nd \\
\hline 2,6-Dimethyl-3-heptene & $\mathrm{C}_{9} \mathrm{H}_{18}$ & nd & nd & nd & $\circ$ & nd \\
\hline Ethyl benzene & $\mathrm{C}_{8} \mathrm{H}_{10}$ & $\circ$ & $\circ$ & $\circ$ & $\circ$ & 0 \\
\hline Styrene & $\mathrm{C}_{8} \mathrm{H}_{8}$ & $\circ$ & $\circ$ & $\circ$ & $\circ$ & $\circ$ \\
\hline 2,4,6-Trimethyl-3-heptene & $\mathrm{C}_{10} \mathrm{H}_{20}$ & $\circ$ & $\circ$ & nd & nd & $\circ$ \\
\hline 4,4,5- Trimethyl-2-hexene & $\mathrm{C}_{9} \mathrm{H}_{18}$ & nd & nd & nd & $\circ$ & nd \\
\hline Cumene & $\mathrm{C}_{9} \mathrm{H}_{12}$ & $\circ$ & nd & nd & nd & nd \\
\hline 1-Methylethylbenzene & $\mathrm{C}_{9} \mathrm{H}_{12}$ & $\circ$ & $\circ$ & $\circ$ & $\circ$ & $\circ$ \\
\hline Phenol & $\mathrm{C}_{6} \mathrm{H}_{6}$ & $\circ$ & nd & nd & $\circ$ & nd \\
\hline 3-Bromo-1-propenyl benzene & $\mathrm{C}_{9} \mathrm{H}_{9} \mathrm{Br}$ & nd & nd & nd & $\circ$ & nd \\
\hline 4,5-Dibromodecane & $\mathrm{C}_{10} \mathrm{H}_{20} \mathrm{Br}_{2}$ & nd & nd & $\circ$ & $\circ$ & nd \\
\hline 1-Bromomethylbenzene & $\mathrm{C}_{8} \mathrm{H}_{9} \mathrm{Br}$ & $\circ$ & nd & nd & nd & nd \\
\hline 3-Bromophenol & $\mathrm{C}_{6} \mathrm{H}_{5} \mathrm{BrO}$ & $\circ$ & nd & $\circ$ & nd & nd \\
\hline 4-Bromo-2,6-dimethylbenzaniline & $\mathrm{C}_{8} \mathrm{H}_{10} \mathrm{BrN}$ & $\circ$ & $\circ$ & nd & nd & nd \\
\hline 1,3-Diphenylpropane & $\mathrm{C}_{15} \mathrm{H}_{16}$ & $\circ$ & $\circ$ & $\circ$ & $\circ$ & $\circ$ \\
\hline
\end{tabular}

$\circ:$ detected, nd : not detected

\subsection{Residue analysis}

The surface of each sample was observed by EDS after pyrolysis to analyze any bromine remaining in the residue and the element distribution maps are shown in Figure 3.
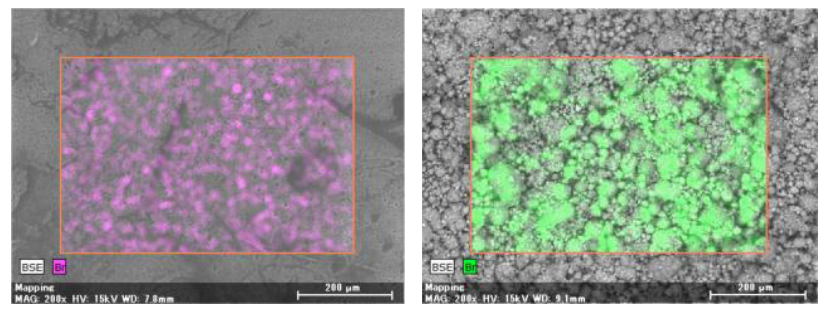

Figure 3. (a). EDS map of condition (b). EDS image of condition $\mathrm{V}$

\subsection{Bromine content in the gas}

The analysis results of the gas generated by pyrolysis are shown in Figure 4 and Table 3. The gas obtained from thermal decomposition was analyzed for brominecontaining compounds. The bromine included in the plastic from the added TBBA was $2 \mathrm{~g}$, and the bromine in the generated gas was $1843 \mathrm{mg}$ for all the conditions. Most bromine was distributed in the product oil and the residue. The decomposition of the plastic causes gases, such as $\mathrm{H}_{2}$ and $\mathrm{CH}_{4}$, to be expelled, but these were low after the addition of HT. This thermal decomposition reaction does not distribute bromine to the gas because of HT, and they are degraded in the product oil and residue.

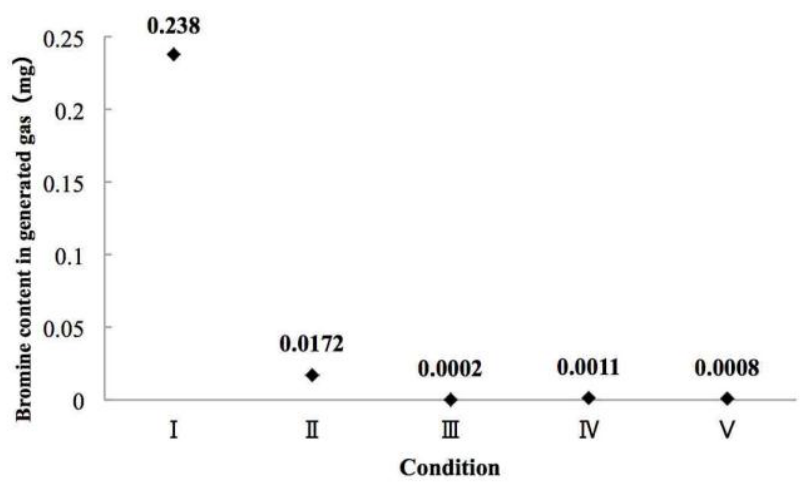

Figure 4. Bromine content in the generated gas 
Table 3. Components of the product gas

\begin{tabular}{|c|c|c|c|c|c|c|}
\hline Condition & $\mathrm{H}_{2}$ & $\mathrm{CH}_{4}$ & $\mathrm{C}_{2} \mathrm{H}_{4}$ & $\mathrm{C}_{2} \mathrm{H}_{6}$ & $\mathrm{C}_{3} \mathrm{H}_{8}$ & $\mathrm{C}_{3} \mathrm{H}_{6}$ \\
\hline I & $\circ$ & nd & nd & nd & $\circ$ & $\circ$ \\
\hline II & $\circ$ & nd & nd & nd & $\circ$ & $\circ$ \\
\hline III & $\circ$ & nd & nd & nd & nd & nd \\
\hline IV & $\circ$ & $\circ$ & $\circ$ & $\circ$ & $\circ$ & $\circ$ \\
\hline V & $\circ$ & nd & nd & nd & $\circ$ & $\circ$ \\
\hline
\end{tabular}

\section{Conclusion}

In this study, we investigated a method of reducing bromine compounds in the product oil obtained by the thermal decomposition of a TBBA-spiked PS and PP mixture using HT. Plastics containing brominated flame retardants can be thermally decomposed to product oils containing no bromine compounds by adding HT. The yield of product oil after adding HT improved. This indicates that the utility of the HT is high, which may be because of a catalytic effect. The residue after adding HT showed more bromine than without additive, suggesting the HT adsorbed the bromine compounds. Thus, the product oil does not contain bromine. The efficacy of plastic thermal decomposition is increased by adding HT, because the bromine compounds are contained in the residue and reduced in product oil.

\section{Acknowlegment}

This work was supported by Mr. Kathunori Suzuki of Tokyo Metropolitan Tama High School of Science and Technology, Japan. N. Morita thanks Mr. Masato Ota and Mr. Yuuta Shimohonji for their cooperation in this study.

\section{References}

1. Jonathan C. Acomb, Mohamad Anas Nahil, Paul T. Williams, "Thermal processing of plastics from waste electrical and electronic equipment for hydrogen production", Journal of Analytical and Applied Pyrolysis, 103, 320-327, (2013)

2. G. Martinho, A. Pires, L. Saraiva, R. Ribeiro, "Composition of plastics from waste electrical and electronic equipment (WEEE) by direct sampling", Waste Management, 32 (6), 1213, (2012)

3. United Nations University, "Review of Directive 2002/96 on Waste Electrical and Electronic Equipment (WEEE); final report", (2008)

4. European Union, "EC, Directive 2002/96/EC Waste Electrical and Electronic Equipment”, L27/34, (2003)

5. Bhaskar T, Matsui T, Kaneko J, Uddin MA, Muto A, Sakata Y Novel calcium based sorbent $(\mathrm{Ca}-\mathrm{C})$ for the dehalogenation $(\mathrm{Br}, \mathrm{Cl})$ process during halogenated mixed plastic (PP/PE/PS/PVC and HIPS-Br) pyrolysis. Green Chem, 4, 372-375, (2002)

6. Grause $\mathrm{G}$, Ishibashi J, Kameda $\mathrm{T}$, Bhaskar $\mathrm{T}$, Yoshioka TKinetic studies of the decomposition of flame retardant containing high-impact polystyrene. Polym Degrad Stab, 95, 1129-1137, (2010)
7. Onwudili JA, Insura N, Williams PTComposition of products from the pyrolysis of polyethylene and polystyrene in a closed batch reactor: Effects of temperature and residence time. $J$ Anal Appl Pyrolysis, 86, 293-303, (2009)

8. Hall WJ, Williams P T Fast pyrolysis of halogenated plastics recovered from waste computers. Energ Fuel, 20, 1536-1549, (2006)

9. Bhaskar T, Uddin MA, Murai K, Kaneko J, Hamano K, Kusaba T, Muto A, Sakata YComparison of thermal degradation products from real municipal waste plastic and model mixed plastics. J Anal Appl Pyrolysis, 70, 579-587, (2003)

10. Serrano DP, Aguado J, Escola JM, Garagorri E Performance of a continuous screw kiln reactor for the thermal and catalytic conversion of polyethylenelubricating oil base mixtures. Appl Catal B, 44, 95105, (2003)

11. Bhask ar T, Matsui T, Uddin MA, Kaneko J, Muto A, Sakata Y Effect of $\mathrm{Sb} 2 \mathrm{O} 3$ in brominated heating impact polystyrene (HIPS-Br) on thermal degradation and debromination by iron oxide carbon composite catalyst (Fe-C). Appl Catal B, 43, 229-241, (2003)

12. Murata K, Hirano Y, Sakata Y, Uddin M A Basic study on a continuous flow reactor for thermal degradation of polymers. J Anal Appl Pyrolysis, 65, 71-90, (2002)

13. Blazso' M, Cze'ge'ny Z, Csoma C Pyrolysis and debromination of flame retarded polymers of electronic scrap studied by analytical pyrolysis. J Anal Appl Pyrolysis, 64, 249-261, (2002)

14. Bockhorn H, Hornung A, Hornung U, Jakobstro“er P, Kraus M Dehydrochlorination of plastic mixtures. J Anal Appl Pyrolysis, 49, 97-106, (1999)

15. Blazso' M, Jakab E Effect of metals, metal oxides, and carboxylates on the thermal decomposition processes of poly(vinyl chloride). J Anal Appl Pyrolysis, 49, 125-143, (1999)

16. R. Luijk, H. Haj, and L. Nelissen, "Formation of polybrominated dibenzofurans during extrusion of high-impact polystylene/decabromodiphenyl ether/antimony (III) oxide," Environ Sci Technol, 26, 2191-2198, (1992)

17. Uemichi Y, Makino Y, Kanazuka T Degradation of polyethylene to aromatic hydrocarbons over metalsupported activated carbon catalysts. J Anal Appl Pyrolysis, 14, 331-344, (1989)

18. A. López, I. de Marco, B.M. Caballero, M.F. Laresgoiti, A. Adrados, A. Aranzabal, "Catalytic pyrolysis of plastic wastes with two different types of catalysts: ZSM-5 zeolite and Red Mud" Applied Catalysis B: Environmental, 104, 211-219, (2011)

19. C. Xie, F. Liu, S. Yu, F. Xie, L. Li, S. Zhang, J. Yang, "Study on catalytic pyrolysis of polystyrene over base modified silicon mesoporous molecular sieve " Catalysis Communications, 9, 1132-1136, (2008)

20. T. Bhaskar et al., "Effect of polyethylene terephthalate (PET) on the pyrolysis of brominated flame retardant-containing high-impact polystyrene (HIPS-Br)," J Mater Cycles Waste Manage, 12, 332340, (2010) 
21. S. Peng et al., "Debromination of flame-retarded TV housing plastic waste,", J Mater Cycles Waste Manage, 12, 103-107, (2010)

22. P. S. Kulkarni, J. G. Crespo, and C. A. M. Afonso, "Dioxins sources and current remediation technologies-a review," Environ Int, 34, 139-153, (2008)

23. C. Vasile, M. A. Brebu, T. Karayildirim, J. Yanik, and H. Darie, "Feedstock recycling from plastic and thermoset fractions of used computers (I): pyrolysis,", J Mater Cycles Waste Manage, 8, 99-108, (2006)

24. R. Luijk, H. Wever, K. Olie, G. Haj, and J. J. Boon, "The influence of the polymer matrix on the formation of polybrominated dibenzo-p-dioxins (PBDDs) and polybrominated dibenzofurans (PBDFs)," Chemosphere, 23, 1172-1183, (1991)

25. X. Yang, L. Sun, J. Xiang, S. Hu, S. Su, "Pyrolysis and dehalogenation of plastics from waste electrical and electronic equipment (WEEE): A review" Waste Management, 33, 462-473, (2013)

26. Research Association For Feedstock Recycling of Plastics Japan, Base and Application of Plastic Recycling, CMC BOOKS Japan, 44ff, (2012)

27. T. Kwon, G. A. Tsigdinos, and T. J. Pinnavaia, "Pillaring of layered double hydroxides (LDH's) by polyoxometalate anions" J. Am. Chem. Soc., 110, 3653-3654, (1988)

28. N. Morita, T. Wajima, and H. Nakagome, "Reduction in Content of Bromine Compounds in the Product Oil of Pyrolysis Using Synthetic Hydrotalcite," International Journal of Chemical Engineering and Applications, 6(4), 262-266, (2015)

29. N. Morita, A. T. Saito, T. Wajima, and H. Nakagome, "Halogen Reduction in Pyrolysis Oil from Brominecontaining Plastics Using Hydrotalcite," Advances in Environment Research , 87, 54-61, (2015)

30. N. Morita, M. Nakayasu, A. T. Saito, T. Wajima, and H. Nakagome, "Effect of Hydrotalcite on Bromine Content in Oil Produced from the Pyrolysis of Acrylonitrile-Butadiene-Styrene Plastics," International Journal of Chemical Engineering and Applications, 7(4), 23-27, (2016)

31. T. Kwon, G. A. Tsigdinos, and T. J. Pinnavaia, "Pillaring of layered double hydroxides (LDH's) by polyoxometalate anions" J. Am. Chem. Soc., 110, 3653-3654, (1988)

32. S. Miyata, " The syntheses of hydrotalcite-like compounds and their structures and physicochemical properties I: The systems $\mathrm{Mg}^{2+}-\mathrm{Al}^{3+}-\mathrm{NO}_{3}{ }^{-}$,
$\mathrm{Mg}^{2+}-\mathrm{Al}^{3+}-\mathrm{Cl}^{-}, \mathrm{Mg}^{2+}-\mathrm{Al}^{3+}-\mathrm{ClO}_{4}^{-}, \mathrm{Ni}^{2+}-\mathrm{Al}^{3+}-\mathrm{Cl}^{-}$and $\mathrm{Zn}^{2+}-\mathrm{Al}^{3+}-\mathrm{Cl}^{-}$," Clays Clay Miner., 23, 369-375, (1975)

33. T. Kameda, M. Nakamura, T. Yoshioka, "Removal of antimonate ions from an aqueous solution by anion exchange with magnesium-aluminum layered double hydroxide and the formation of a brandholzite-like structure." Journal of Environmental Science and Health, Part A, 47, 11461151, (2012)

34. T. Kameda, K. Hoshi, T. Yoshioka, "Uptake of Sc ${ }^{3+}$ and $\mathrm{La}^{3+}$ from aqueous solution using ethylenediaminetetraacetate-intercalated $\mathrm{CuAl}$ layered double hydroxide reconstructed from $\mathrm{CuAl}$ oxide." Solid State Sciences, 13, 366-371, (2011)

35. K. Ralla, U. Sohling, K. Suck, F. Sander, C. Kasper, F. Ruf, T. Scheper, "Adsorption and separation of proteins by a synthetic hydrotalcite" Colloids and Surfaces B, Biointerfaces, 87, 217-225, (2011)

36. K. J. Martin, and T. J. Pinnavaia, "Layered double hydroxides as supported anionic reagents. Halide-ion reactivity in zinc chromium hexahydroxide halide hydrates $\left[\mathrm{Zn}_{2} \mathrm{Cr}(\mathrm{OH})_{6} \mathrm{X} \cdot \mathrm{nH}_{2} \mathrm{O}\right](\mathrm{X}=\mathrm{Cl}, \mathrm{I})$, ' J. Am. Chem. Soc., 108, 541-542, (1986)

37. T. Kameda, N. Uchiyama, T. Yoshioka, "Removal of $\mathrm{HCl}, \mathrm{SO}_{2}$, and $\mathrm{NO}$ by treatment of acid gas with $\mathrm{Mg}-\mathrm{Al}$ oxide slurry" Chemosphere, 82, 587-591, (2011)

38. E. Suzuki, M. Okamoto, and Y. Ono, "Catalysis by interlayer anions of a synthetic hydrotalcite-like mineral in a halide exchange between organic halides," Chem. Lett., 18, 1485-1486, (1989)

39. Kazuya Morimoto, Sohtaro Anraku, Jun Hoshino, Tetsuro Yoneda, Tsutomu Sato, "Surface complexation reactions of inorganic anions on hydrotalcite-like compounds" Journal of Colloid and Interface Science, 384, 99-104, (2012)

40. Lin Deng, Zhou Shi, "Synthesis and characterization of a novel $\mathrm{Mg}$-Al hydrotalcite-loaded kaolin clay and its adsorption properties for phosphate in aqueous solution", Journal of Alloys and Compounds, 637, 188-196, 2015.

41. Ganapati D. Yadav, Payal A. Chandan, "A green process for glycerol valorization to glycerol carbonate over heterogeneous hydrotalcite catalyst", Catalysis Today, 237, 47-53, 2014. 